\title{
Investigating the effects of foreign direct investments on Croatian business
}

\author{
Journal of High Technology Management Research
}

Volume 28, Issue 2, 2017, Pages 208-220

\begin{abstract}
Yonghee Cho
Engineering and Technology Management, Portland State University, 1900 SW Fourth Ave. Portland OR 97201, USA

E-mail: yonghee@pdx.edu
\end{abstract}

Tugrul U. Daim

Department of Engineering and Technology Management, Portland State University, OR 97207, USA

E-mail: ji2td@pdx.edu

Dabic Marina

Faculty of Economics, Zagreb, Trg J. F. Kennedy 6, HR-10000 Zagreb, Croatia E-mail: dabicmarina@gmail.com

\begin{abstract}
The purpose of this study is to analyze the effects of foreign direct investments (FDI) on businesses in partial or complete foreign ownership, with a special emphasis on technology transfer, and to assess the impact of foreign companies on domestic firm performance through technology transfer from foreign companies. This paper aims to investigate the investment climate for foreign investments and intensify technology transfers and innovations in the Croatian economy. 145 firms responded to the survey we conducted for foreign investment enterprises in Croatia. Structural equation model is employed to examine the hypotheses with respect to effects of FDI on innovation activities of domestic Croatian firms. This study identified major factors affecting technology innovation to Croatian firms.
\end{abstract}


Keywords: Foreign Direct Investment (FDI), Technology Transfer, Technology Innovation, Structural Equation Model

\section{Introduction}

In recent years, emerging economies have gained much attention to multinational corporation (MNC) operations since their market have been growing fast. Within this context, understanding the determinants of foreign direct investment (FDI) is particularly significant, since FDI can play an important role as an engine in the transition from the underdeveloped to the developed economy and as a powerful source to integrate this region into the global economy. FDI is one of the most effective channels through which technology can be transferred across countries. FDI gives direct and indirect impact on economic growth in host economies. In this regard, Blomström et al. identified direct impact of FDI on the host country such as employment, capital, exports, and new technology (Blomström, Kokko, \& Zejan, 2000).

In the expansion of multinational corporations (MNCs), technology transfer to local subsidiaries is essential for successful operation of the subsidiaries in the local market (Chung, 2001). Transferred technology helps local subsidiaries of MNCs modify their product features to meet demand of the local market (Cui, Griffith, Cavusgil, \& Dabic, 2006). This paper examines the effects of technology spillovers on the business performance of local companies as well as on the industry conditions that favor technology transfer. This study focuses on analyzing the effects of foreign investments on businesses in partial or complete foreign ownership, with a special emphasis on technology transfer. This research will form the basis for recommendations aimed at improving the investment climate for foreign investments and intensifying technology transfers and innovations in the economy. The purpose of this study is to assess the impact of MNCs on the business performance of domestic firm through technology transfer. With respect to the growth of emerging market benefited from FDI, we may raise following research questions.

- RQ: What are the motives of foreign investors and how they vary?

- RQ: How does the type of foreign ownership in the FDI affect the degree of technology spillovers?

- RQ: What is the impact of foreign ownership on the technology transfer?

- RQ: What is the role of the subsidiary regarding technology transfer?

- RQ: Does internal innovation activity promote the technology transfer? 
- RQ: Does the intensity of technology transfer depend on the size of a firm?

- RQ: Does the intensity of technology transfer have positive relationship with business performance?

Despite the extensive theoretical and empirical literature, empirical study on the roles of technology transfer and adoption, innovation, firm organization, and the feedback loop from FDI remains still scare. We contribute to the literature on FDI by investigating if the firm size, intensity of innovation activities, and the type of ownership have any effect on performance and the degree of technology spillovers. Seven hypotheses associated with research questions in terms of FDI have been derived through the literature review. The hypotheses were examined using statistical test as well as structural equation model based upon the work done by Dabic et al (Dabić, Daim, Aralica, \& Bayraktaroglu, 2012). All 145 respondents to the survey are manufacturing firms which are subsidiaries of foreign multinational enterprises in Croatia. This paper is organized as follows. The section 2 discusses the fundamentals of the technology transfer and FDI. Hypotheses and theoretical research models are presented in section 3. This is followed by the results of the data analyses conducted. Finally, the study concludes with the discussion of the results.

\section{Theoretical background}

Ethier indicated three key elements of FDI by multinational firms: ownership advantage, locational considerations, and internalization of international transactions (Ethier, 1986). Johanson and Vahlne also developed the model of the internationalization process of the firm that focuses on integration, use of knowledge about foreign markets, and the commitment to foreign markets (Johanson \& Vahlne, 1977). This model describes the process involving a series of incremental steps, when a firm expands its operations. Overcoming the lack of experience and knowledge on multinational expansion depends on the firm's absorptive capacity (Cohen \& Levinthal, 1989). Cohen and Levinthal defined absorptive capacity as "a firm's capability to recognize value of new, external knowledge, assimilate it, and apply it to commercial ends" (Cohen \& Levinthal, 1990). Lane and Lubatkin further developed this rationale by arguing that the knowledge transfer from another company is jointly determined by the relative characteristics 
of recipient firm and MNCs based on the type of knowledge, the similarity between two firm's compensation practices and organizational structures, and the recipient firm's familiarity with MNCs' set of organizational problems (Lane \& Lubatkin, 1998). Zahra and George extended the concept of absorptive capacity to incorporate a set of organizational routines and strategic processes by which firms manage knowledge, putting emphasis on dynamic capabilities (Zahra $\&$ George, 2002). Pennings and Harianto investigated the role of absorptive capacity for banking industry and suggested prior experience is more significant than asset investments (Pennings \& Harianto, 1992). Such knowledge and experience is described as ownership.

On the other hand, many studies focus on the complementary effects from FDI. In this regard, friendly local policies and business environments are prerequisite for knowledge spillovers from MNCs. Luo and Park characterized specific environments such as dynamism, complexity, and hostility to affect technology transfer at the MNC subsidiary level (Luo \& Park, 2001). Cui et al. also examined the effects of market and cultural environmental factors on technology transfer from MNCs (Cui et al., 2006). Bénassy-Quéré et al. demonstrated institutional quality such as bureaucracy, corruption, information, banking sector, and legal institutions as significant determinants of inward FDI (Bénassy-Quéré, Coupet, \& Mayer, 2007). Griffith et al. estimated the productivity of UK-based companies caused by knowledge spillovers from foreign R\&D investment to domestic firms, proposing five percent increase of their productivity on average (Griffith, Harrison, \& Reenen, 2006). Thus, it is important to note that MNCs have expanded their role from downstream activities to upstream ones such as R\&D and strategic marketing (Mudambi \& Navarra, 2004).

Moreover, FDI is divided into two forms of investment: cross-border mergers and acquisitions (M\&A) or greenfield investment (J.-F. Hennart \& Park, 1993). Both type of FDI lead to domestic investment in a host country. When compared to greenfield subsidiaries, acquired subsidiaries on average can be relatively expected to have a non-duplicative knowledge stock (Gupta \& Govindarajan, 2000). Based on the transaction cost theory, Gomes-Casseres suggested that MNCs prefer joint venture over wholly owned subsidiary, when the capabilities of the local firm complement those of the MNC (Gomes-Casseres, 1989). Based on the results from a panel data of 53 countries from 1996 to 2006, Neto et al. proposed that FDI through greenfield investments has a positive association with economic growth in both developed and developing countries, while M\&A have a negative effect on economic growth in only developing countries 
(Neto, Brandão, \& Cerqueira, 2010). Thus, prior research has paid much attention to the impact of FDI on economic growth in host countries, particularly in developing countries in the literature. This study aims at contributing to the body of knowledge concerning FDI by providing an empirical piece on a country that is not well known to researchers, thereby leading to a better understanding of how FDI contributes to the underdeveloped local economy.

\section{Hypothesis development}

Based on the survey result, we first examined each link longitudinally using only two waves of data in the survey instrument, because there are available predictor and outcome variables measured at two time points. We, however, could not find sufficient statistical significance to analyze cross-lagged analysis in given dataset with many missing data. In this section, the hypotheses are addressed. Analyses and statistical results are discussed in the next section. The research hypotheses derived from the research questions and literature reviews are presented in Table 1.

Table 1. Research Questions and Hypothesis

\begin{tabular}{|c|c|}
\hline Research Questions & Hypothesis \\
\hline $\begin{array}{l}\text { RQ1: What are the motives of foreign investors } \\
\text { and how they vary? } \\
\text { RQ2: How does the type of foreign ownership in } \\
\text { the FDI affect the degree of technology } \\
\text { spillovers? } \\
\text { RQ3: What is the impact of foreign ownership on } \\
\text { technology transfer? }\end{array}$ & $\begin{array}{l}\text { H1: The relative importance of motives will vary } \\
\text { with the market entry mode } \\
\text { H2: The relative importance of motives will } \\
\text { differ based on the ownership pattern of the } \\
\text { equity (i.e. wholly owned subsidiaries (WOSs) or } \\
\text { joint ventures (JVs) } \\
\text { H3: The higher foreign ownership leads to more } \\
\text { efficient technology transfer }\end{array}$ \\
\hline $\begin{array}{l}\text { RQ4: What is the role of the subsidiary regarding } \\
\text { technology transfer? } \\
\text { RQ5: Does internal innovation activity promote } \\
\text { technology transfer? } \\
\text { RQ6: Does the intensity of technology transfer } \\
\text { depend on the size of a firm? } \\
\text { RQ7: Does the intensity of technology transfer } \\
\text { have a positive relationship with business } \\
\text { performance? }\end{array}$ & $\begin{array}{l}\text { H4: Abroad subsidiaries are positively correlated } \\
\text { with technology transfer of foreign investment } \\
\text { companies } \\
\text { H5: The higher domestic innovation intensity } \\
\text { boost efficacy of technology transfer } \\
\text { H6: The size of a firm will affect technology } \\
\text { transfer activities within organization } \\
\text { H7: Technology transfer between MNC and local } \\
\text { subsidiaries has a positive association with the } \\
\text { business performance of MNC subsidiaries }\end{array}$ \\
\hline
\end{tabular}

\subsection{Foreign ownership, motivation and technology transfer}


The choice of an appropriate entry mode is one of the most critical decisions in FDI, since it determines the degree of resource commitment and control over subsidiaries (Morschett, Schramm-Klein, \& Swoboda, 2010). Moreover, market entry modes are difficult to change, once established, due to contractual restrictions as well as switching costs (Pedersen, Petersen, \& Benito, 2002). The typical forms of market entry modes include exporting, licensing, subsidiary's ownership mode (joint venture (JV) or wholly-owned subsidiary (WOS)) and subsidiary's establishment mode (greenfield or acquisition) (Dikova \& van Witteloostuijn, 2007)(J.-F. Hennart \& Slangen, 2015). Based on the type of ownership of its venture, a firm must make a decision whether to engage in acquisition or to establish a new venture from scratch (green-field investment).

The selection of foreign entry modes in FDI are influenced by various factors such as transaction cost (Erin Anderson \& Gatignon, 1986)(J. Hennart, 1988)(Boeh \& Beamish, 2012), institutional pressures (Yiu \& Makino, 2002), resource/knowledge-based advantages (Brouthers, Brouthers, \& Werner, 2008)(Kogut \& Zander, 1993) and eclectic OLI (Dunning, 1988)(Hill, Hwang, \& Kim., 1990). Hence, a firm's choice of foreign market entry mode depends on its ownership benefits, the geographical merits of the host country, and internalization advantages of international transactions. The focus of this study is on the distinction between JVs and WOSs. Wholly owned entry modes offer greater control over foreign operations, whiles joint ventures allow a limited ownership over local partners (Yiu \& Makino, 2002). There has been a controversial debate on the distinction between JVs and WOSs. In general, a majority owned JV has more than $50 \%$ equity stake. If foreign equity ownership is equal to $50 \%$, the $\mathrm{JV}$ is considered co-owned (Makino \& Beamish, 1998). Makino and Beamish used an $80 \%$ equity ownership cutoff based on traditional accounting rules (Makino \& Beamish, 1998). Many studies, however, have adopted a $95 \%$ foreign equity ownership as the cutoff point (Stopford \& Wells, 1972)(Erin Anderson \& Gatignon, 1986)(Gomes-Casseres, 1989)(J.-F. Hennart, 1991)(Padmanabhan \& Cho, 1996)(Yiu \& Makino, 2002). Hence, this study also considers the firm which has greater than $95 \%$ foreign equity shareholding as WOS. In consequence, this study investigated the association between the motives of entry, the market entry mode, and the ownership pattern of the equity.

\section{H1. The relative importance of motives will vary with the market entry mode}




\section{H2. The relative importance of motives will differ based on the ownership pattern of the equity (i.e. wholly owned subsidiaries (WOSs) or joint ventures (JVs)}

MNCs have a tendency to transfer advanced and appropriate technology to subsidiaries since they may have a willingness to take advantage of proprietary technology given its equity stake in the subsidiaries (Hu, Jefferson, \& Jinchang, 2005). MNC-subsidiary links may help reduce technological dependence on external resources. Foreign invested firms may have benefit of reducing the transaction costs of new technology within MNC-subsidiary channels. MNCs can help local partners to identify appropriate technologies to acquire from other entities. Moreover, ownership structure affects the subsidiary's absorptive capacity that may influence technology transfer (Sinani \& Meyer, 2004). Thus, FDI via equity ownership is an important channel of technology transfer.

Many studies investigated the effect of foreign ownership on the efficacy of technology transfer. There has been a mixed support for the association between foreign ownership and technology transfers. Blomström and Sjöholm find no evidence of technology transfer associated with foreign ownership (Blomström \& Sjöholm, 1999). Ramachandran, however, pointed out that WOS received more resources for technology transfer than a partial equity ownership (Ramachandran, 1993). Javorcik indicated that the extent of technology spillovers has a positive association with JV rather than WOS (Javorcik, 2004). Sinani and Meyer proposed evidence that the level of technology spillovers is larger in foreign-owned firms rather than domestic-owned firms (Sinani \& Meyer, 2004). Hu et al. supported that foreign equity participation promotes technology transfer from MNC to subsidiaries (Hu et al., 2005). In this regard, it is crucial for subsidiaries and policy makers to understand which types of foreign ownership structure will provide the greatest benefits for their national economy.

\section{H3. The higher foreign ownership leads to more efficient technology transfer}

\subsection{The extent of linkages}

To fully understand potential technology spillovers of FDI, we must take into account the association between vertical linkages, subsidiary roles, MNC strategy, and technology transfer and diffusion. First, vertical linkages between foreign subsidiaries and local firms depend on 
subsidiaries' objectives and activities such as R\&D, manufacturing, global/local balance within MNC network (Marin \& Bell, 2006). In this regard, based on the knowledge flows within the MNC, Gupta and Govindarajan categorized subsidiary's strategic roles into four dimensions: global innovator, integrated player, local innovator, and implementor (Gupta \& Govindarajan, 1991)(Gupta \& Govindarajan, 1994). Thus, the subsidiary's role will decide the potential for knowledge transfer from its MNC, linkages intensity, a level of autonomy, and potential technology diffusion to local firms. Of course, the subsidiary's role might be changed by subsidiary capabilities that are evolutionary in nature (Frost, Birkinshaw, \& Ensign, 2002) as well as MNC's strategies (Harzing \& Noorderhaven, 2006).

The relationship between vertical linkages and subsidiary roles within the MNC network may affect technology transfers from a parent MNC to subsidiaries (Gupta \& Govindarajan, 2000)(Harzing \& Noorderhaven, 2006). A variety of factors affect the level of subsidiary strategic independence such as subsidiary bargaining power, the degree of research intensity of the subsidiary within the firm, and location (Cantwell \& Mudambi, 2005)(Mudambi \& Navarra, 2004). Subsidiary strategic independence in the MNC network plays an important role in enhancing technology transfer. Relational embeddedness at the subsidiary level may influence on their market performance as well as competence development in the developing economies (Andersson, Forsgren, \& Holm, 2002). Hence, technology transfer is feasible since subsidiaries are able to acquire strategic independence in R\&D activities of their operations (Mudambi \& Navarra, 2004).

H4: Abroad subsidiaries are positively correlated with technology transfer of foreign investment companies

\subsection{Innovation intensity and technology transfer}

Many studies have examined the associations between domestic R\&D, technology transfer, and FDI. With more increasing equity participation in subsidiaries, the parent firm has more propensity to take advantage of advanced technologies of host countries (Hu et al., 2005). There, however, exist controversial arguments regarding complementary or substitute relationship between technology transfer and internal R\&D effort (Perez, 1997)(Görg \& Greenaway, 2004)(Spencer, 2008). Guellec and de la Potterie indicated that international cooperation in R\&D 
has been increased and the internationalization of technology is higher for the lower level of innovation intensity (Guellec \& de la Potterie, 2001). de la Potterie and Lichtenberg suggested that outward FDI and import flows have a positive impact on technology spillovers (de la Potterie \& Lichtenberg, 2001). Hu et al. found evidence that FDI is more likely to weaken technological innovation in the host economy (Hu et al., 2005).

Based on the belief that R\&D and technology transfer have a complementary association, Cohen and Levinthal argued that research and development plays two different roles; it not only simulates technological innovation but also enhances a firm's ability to assimilate and apply new technology (Cohen \& Levinthal, 1989). MNC's technology can be transmitted to local firms through following channels: demonstration effects, local linkages, employment and labor turnover, competition effects (Spencer, 2008)(Blomström et al., 2000)(Blomström \& Kokko, 1998). MNCs create forward and backward linkages as they build relationships with suppliers or distributors in their host countries (Markusen \& Venables, 1999). The forward and backward linkages can play a vital role of mediators in transferring technology from one company to another (Spencer, 2008). In addition, local firms may emulate MNC's activities such as business strategy, pricing, marketing approaches, new technologies, and organizational practices (Blomström \& Kokko, 1998). Consequently, technology transfer and diffusion is likely to be higher in case the subsidiary regards innovation as a critical source of its own competitive advantages. When combined with indigenous innovation activities, it will promote the efficacy of MNC's technology transfer.

\section{H5. The higher domestic innovation intensity boost efficacy of technology transfer}

\subsection{Firm size and technology transfer}

Technological opportunities are conditioned by firm size (Pavitt, Robson, \& Townsend, 1989). In general, large firms can have technical and managerial talent and critical complementary assets in order to exploit innovative opportunities, while as small firms may have difficulty in absorbing new technology due to lack of managerial and technical competence (Sinani \& Meyer, 2004)(Teece, 1977). Acs et al. pointed out that small firms have a propensity to take advantage of external technology source for generating innovation (Acs, Audretsch, \& 
Feldman, 1994). On the other hand, we have encountered competent small firms creating technology as important sources of innovation.

There has been a mixed support concerning the effect of firm size on technology transfer. Aitken and Harrison found no evidence that local firm size affect technology spillovers (Aitken \& Harrison, 1999). However, Buckley et al. presented evidence that local partner's size is an important factor in developing new products and exporting goods in the host economy (Buckley, Clegg, \& Wang, 2002). Sinani and Meyer indicated that small firms gains benefit from technology transfer of MNCs rather than medium and large firms (Sinani \& Meyer, 2004). Subsidiaries' size has a positive relationship with the intensity of forward (from supplier to buyer) linkages (Jindra, Giroud, \& Scott-Kennel, 2009). Subsidiaries via vertical linkages with MNC may be affected by their technological competencies. This leads to a better understanding of how MNC contribute to local firms and the host economy. Consequently, this study investigates the effect of firm size on the technology transfer of MNCs in Croatia.

\section{H6: The subsidiary's size will affect technology transfer activities within organization}

\subsection{Technology transfer and business performance}

Technology transfer is a typical form of research transformation and the result of technology diffusion activities. Technology transfer, linkages, and spillovers of MNCs are critical for the host countries, which consider MNC's role as engines of their economic growth. MNC's technology transfer depends on its motives or strategy to oversea subsidiaries. Subsidiaries' role might affect technology transfer activities between them in the host country. Technology transfer through FDI is also influenced by the motives and absorptive capabilities of local subsidiaries (Young \& Lan, 1997). On the other hand, technology transfer brings about the concern of the technology dissipation from MNC in the home country. Nevertheless, MNCs typically expand their business operations abroad for improving operational efficiency by utilizing advantages of the host country such as location, labor, raw materials, supply chains, and other resources (Pack \& Saggi, 2001)(Cusumano \& Elenkov, 1994). When MNCs expand their operation abroad to obtain comparative advantage, technology is likely to be localized to meet the market conditions (Chung, 2001). Hence, MNC tends to transfer its technology to oversea subsidiaries for the successful operation in the local market. As a result of effective technology transfer from MNC, 
subsidiaries may not only reduce the cost of existing operations but also improve productivity (Hu et al., 2005)(Patterson, 1983). The technology transferred to oversea subsidiaries can help them acquire market share by improving product quality as well as reducing production cost (Cui et al., 2006). Blalock and Gertler provided evidence that local partners gain productivity and lower prices through technology transfer from MNC (Blalock \& Gertler, 2008). Technology diffusion, however, is not the automatic consequence of MNC's efforts but it depends on absorptive capability of local partners by investing in learning and $R \& D$ activities.

Over several decades, there has been still considerable controversy over the effects of MNC's technology transfer to its oversea subsidiaries in the host economy. de la Potterie and Lichtenberg indicated that inward FDI has no effect on technology transfer from MNC to subsidiaries (de la Potterie \& Lichtenberg, 2001). Cui et al. supported positive relationship between technology transfer and the performance of MNC subsidiaries through FDI (Cui et al., 2006). Javorcik indicated that local partners gain productivity benefits in case of partial ownership through FDI (Javorcik, 2004). Blalock and Gertler also suggested that technology transfer from MNC increases productivity, output and profits (Blalock \& Gertler, 2008). Thus, vertical linkages are a conduit for technology diffusion from FDI in the host economy, which generates subsidiaries' financial performance. In sum, we examine whether technology diffusion from MNC generates the efficacy of business performance of subsidiaries in the host market.

H7. Technology transfer from the MNC to subsidiaries has a positive association with the business performance of subsidiaries.

This paper attempts to examine the association between several dimension of the technology transfer such as firm size, innovation intensity, and foreign ownership as previously described. These measures have been extensively used in past research on examining the association between technology transfer and business in a firm. The research model of this study is illustrated to support for the research hypotheses in Figure 1. 


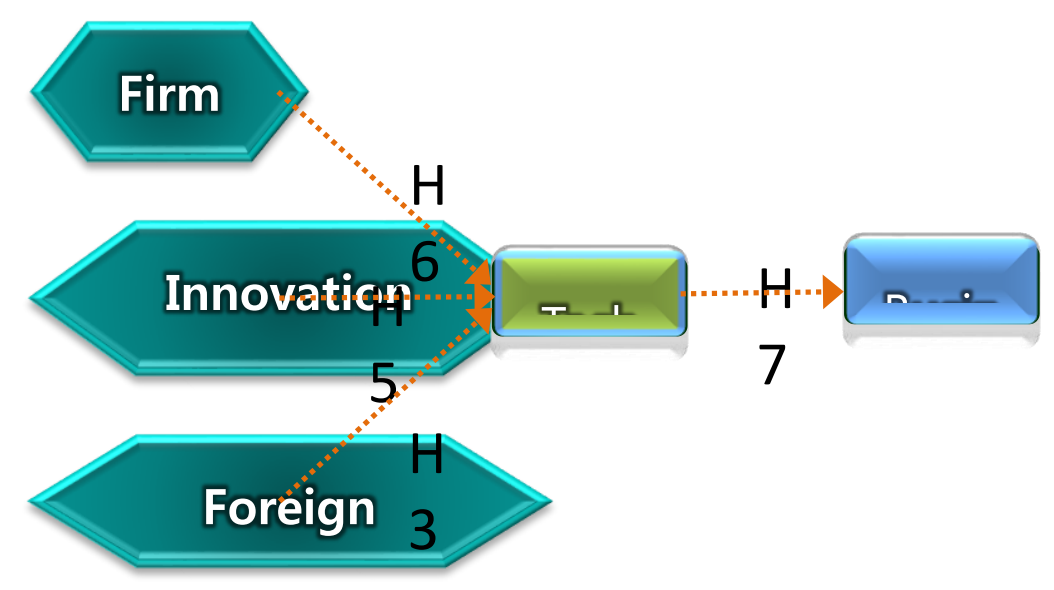

Fig. 1 Research Model

\section{Research method and data collection}

To answer to research questions, ANOVA, confirmatory factor analysis (CFA), and structural equation modeling (SEM) are employed to investigate not only group difference for the subject matter of technology transfer but also causal relationship among variables, and finally statistically test hypotheses proposed in Figure 1, based on the literature review. SEM is an appropriate tool to analyze path model with latent variables in order to uncover causal structures. The hypothesized relationships in this model have multiple intercorrelations between a set of variables, which are developed based on literature review and hypothetical assumptions. A straight, one-headed arrow represents a causal association between two variables. This model cannot be solved by ordinary least squares (OLS) regression techniques. Multiple regression can be regarded a special case of SEM (Pedhazur, 1997). By contrast, SEM approach is a multivariate tool that takes into account complete and simultaneous equation of all relationship in a given model. SEM approach allows us to easily articulate relationships of all variables with one another (Maruyama, 1998). This research focuses on the causal inference in latent variable models. Causal relationship is the focal point of SEM analysis (Pedhazur, 1997). Path model incepted in population genetics to model inheritance by Sewall Wright in 1918 (Wright, 1918) and later widely applied to various situations in psychology and sociology (Bollen, 2002). Path models and multiple regression provide the core information needed to understand the broad class of SEM (Maruyama, 1998). Path analysis gauges the strength of causal relations among variables in a multiple systems of equations based on the correlation matrix of observed variables 
(Wright, 1934). In the 1970s cross-disciplinary integration ended up with structural equation modeling. SEM mainly deals with the specification of causal relations among variables. Path modeling is integrated with logic of factor analysis (Maruyama, 1998). Based on the groundwork Karl Pearson and Charles Spearman made in 1900s, factor analysis was developed to explore the structure of intelligence in multivariate data (Matsueda, 2012). Factor analysis has been widely used for the analysis of correlated data (Ford, MacCallum, \& Tait, 1986). Factor analysis is designed to link factors to measures that are defined in terms of weights (Maruyama, 1998). CFA requires the specification of particular factor structure, whereas EFA allows all items to load on all factors (Newsom, 2015). CFA approach attempts to examine whether or not observed data are consistent with the posited theoretical model. CFA provides a chi-square test and goodness-of-fit indicators.

This paper uses secondary data from the Institute of Economics, Zagreb which is one of the major social science research institutions in the Croatia. They conducted this survey in 2007 and collected survey responses from private companies invested from foreign multinational company in the Croatia to improve the investment climate for foreign investments and the intensifying technology transfers and innovations in the Croatia. Survey questionnaire consists of three parts which are background information, the relationship between a firm and foreign investor, and R\&D, innovation in a firm. 22 closed-ended questions and 1 basic information question were developed for this survey. A total of 145 firms responded to this survey. According to This et al (Dabić, Daim, Aralica, \& Bayraktaroglu, 2012) foreign investment enterprises in manufacturing sector were the respondents. Any respondent was a foreign legal entity or person holding a minimum of $10 \%$ of equity of another company in Croatia. The survey was conducted in April and May of 2007. The targeted sample contained 250 enterprises. This was acquired from the Croatian Bureau for Business Intelligence database. This data base has the records domestic and/or foreign ownership in Croatian business. The companies in the sample were first contacted by mail with follow-up phone calls and e-mails. The total of 145 firms who responded to the survey resulted in a response rate of $66 \%$.

\section{Data analysis and results}


The foreign investors' motives are presented in Table 2 ranked by the mean value for the importance of the five motives at the initial entry and today. Market access has the highest ranking foreign investors' motive, which indicates that MNCs are mostly interested in market development in Croatia. Relatively increased efficiency ranks second perceived as an important motive reflecting the market-seeking investment of MNCs.

Table 2. Relative importance of motives of foreign investors

\begin{tabular}{|l|r|r|r|}
\hline \multicolumn{1}{|c|}{ Motivation } & \multicolumn{1}{c|}{ Rank } & \multicolumn{1}{c|}{ Mean } & Std. Deviation \\
\hline Market access - today & 1 & 3.50 & 1.364 \\
\hline Market access - entry & 2 & 3.48 & 1.346 \\
\hline Increased efficiency - today & 3 & 3.43 & 1.289 \\
\hline Increased efficiency - entry & 4 & 3.26 & 1.241 \\
\hline Access to local knowledge, skills - today & 5 & 3.08 & 1.265 \\
\hline Access to local knowledge, skills - entry & 6 & 2.81 & 1.196 \\
\hline Access to natural resources - today & 7 & 2.25 & 1.392 \\
\hline Access to natural resources - entry & 8 & 2.19 & 1.353 \\
\hline Following key clients - today & 9 & 2.09 & 1.243 \\
\hline Following key clients -entry & 10 & 1.92 & 1.092 \\
\hline
\end{tabular}
$\mathrm{N}=106$

The mean is the average on a scale of 1 (not important) to 5 (extremely important)

ANOVA was conducted to test whether there is significant difference in the relative importance of motives based on the five market entry modes. The relatively weak supports for Hypothesis 1 are found, in that for three out of ten factors - market access at entry and market access at today $(\mathrm{p}<0.5)$ - are there significant differences in the mean value. The results reveal the foreign investors' motive that they prefer acquisition of a local firm (private-public ownership) over other types of entry mode. In addition, this study found significant difference in the mean value of 'access to natural resources at entry $(\mathrm{p}<0.5)$ ', which indicates MNCs' motive that intend to acquire a firm from another prior foreign investor over other types of entry mode.

Table 3. The motivation of foreign equity shareholder in Croatia: initial mode of entry

\begin{tabular}{|c|c|c|c|c|c|c|}
\hline Motivation & Group & $\mathrm{N}$ & Mean & $\begin{array}{c}\text { Std. } \\
\text { Deviation }\end{array}$ & $\mathrm{F}$ & Sig. \\
\hline Market access - entry & Acquisition of state owned firm in privatization & 21 & 3.19 & 1.401 & 2.829319 & 0.028 \\
\hline
\end{tabular}




\begin{tabular}{|c|c|c|c|c|c|c|}
\hline & $\begin{array}{l}\text { Acquisition of domestic private firm } \\
\text { Acquisition of a domestic firm (private-public ownership) } \\
\text { Acquisition from another prior foreign investor } \\
\text { Ownership of completely new enterprise } \\
\text { Total }\end{array}$ & $\begin{array}{r}23 \\
17 \\
7 \\
46 \\
114\end{array}$ & $\begin{array}{l}3.00 \\
4.24 \\
4.00 \\
3.50 \\
3.48\end{array}$ & $\begin{array}{r}1.382 \\
.752 \\
.816 \\
1.378 \\
1.325\end{array}$ & & \\
\hline Market access - today & $\begin{array}{l}\text { Acquisition of state owned firm in privatization } \\
\text { Acquisition of domestic private firm } \\
\text { Acquisition of a domestic firm (private-public ownership) } \\
\text { Acquisition from another prior foreign investor } \\
\text { Ownership of completely new enterprise } \\
\text { Total }\end{array}$ & \begin{tabular}{r|}
20 \\
23 \\
15 \\
8 \\
48 \\
114 \\
\end{tabular} & \begin{tabular}{l|}
3.20 \\
3.35 \\
4.47 \\
3.75 \\
3.35 \\
3.50 \\
\end{tabular} & \begin{tabular}{r|}
1.436 \\
1.434 \\
.640 \\
1.165 \\
1.407 \\
1.365 \\
\end{tabular} & 2.527959 & $0.045^{* *}$ \\
\hline Following key clients -entry & $\begin{array}{l}\text { Acquisition of state owned firm in privatization } \\
\text { Acquisition of domestic private firm } \\
\text { Acquisition of a domestic firm (private-public ownership) } \\
\text { Acquisition from another prior foreign investor } \\
\text { Ownership of completely new enterprise } \\
\text { Total }\end{array}$ & \begin{tabular}{r|}
20 \\
17 \\
16 \\
7 \\
43 \\
103 \\
\end{tabular} & $\begin{array}{l}2.10 \\
1.82 \\
2.25 \\
2.43 \\
1.65 \\
1.91\end{array}$ & \begin{tabular}{r|}
1.252 \\
1.015 \\
1.125 \\
.787 \\
.948 \\
1.058 \\
\end{tabular} & 1.712387 & 0.153346 \\
\hline Following key clients - today & $\begin{array}{l}\text { Acquisition of state owned firm in privatization } \\
\text { Acquisition of domestic private firm } \\
\text { Acquisition of a domestic firm (private-public ownership) } \\
\text { Acquisition from another prior foreign investor } \\
\text { Ownership of completely new enterprise } \\
\text { Total }\end{array}$ & $\begin{array}{r}20 \\
17 \\
15 \\
6 \\
46 \\
104 \\
\end{array}$ & $\begin{array}{l}2.20 \\
2.06 \\
2.47 \\
2.33 \\
1.85 \\
2.07\end{array}$ & \begin{tabular}{r|}
1.281 \\
1.298 \\
1.356 \\
.816 \\
1.192 \\
1.233 \\
\end{tabular} & 0.882008 & 0.477671 \\
\hline Increased efficiency - entry & $\begin{array}{l}\text { Acquisition of state owned firm in privatization } \\
\text { Acquisition of domestic private firm } \\
\text { Acquisition of a domestic firm (private-public ownership) } \\
\text { Acquisition from another prior foreign investor } \\
\text { Ownership of completely new enterprise } \\
\text { Total }\end{array}$ & \begin{tabular}{r|}
21 \\
19 \\
16 \\
6 \\
46 \\
108 \\
\end{tabular} & $\begin{array}{l}.10 \\
3.63 \\
2.94 \\
3.83 \\
3.20 \\
3.25 \\
\end{array}$ & \begin{tabular}{r|}
1.091 \\
1.300 \\
1.340 \\
.983 \\
1.293 \\
1.254 \\
\end{tabular} & 1.119406 & 0.351506 \\
\hline Increased efficiency - today & $\begin{array}{l}\text { Acquisition of state owned firm in privatization } \\
\text { Acquisition of domestic private firm } \\
\text { Acquisition of a domestic firm (private-public ownership) } \\
\text { Acquisition from another prior foreign investor } \\
\text { Ownership of completely new enterprise } \\
\text { Total }\end{array}$ & \begin{tabular}{r|}
21 \\
19 \\
16 \\
6 \\
46 \\
108 \\
\end{tabular} & $\begin{array}{l}3.14 \\
3.95 \\
3.25 \\
4.33 \\
3.28 \\
3.43 \\
\end{array}$ & \begin{tabular}{r|}
1.153 \\
1.079 \\
1.390 \\
.816 \\
1.377 \\
1.291 \\
\end{tabular} & 2.062328 & 0.091147 \\
\hline $\begin{array}{l}\text { Access to natural resources - } \\
\text { entry }\end{array}$ & $\begin{array}{l}\text { Acquisition of state owned firm in privatization } \\
\text { Acquisition of domestic private firm } \\
\text { Acquisition of a domestic firm (private-public ownership) } \\
\text { Acquisition from another prior foreign investor } \\
\text { Ownership of completely new enterprise } \\
\text { Total }\end{array}$ & \begin{tabular}{r|}
21 \\
20 \\
16 \\
6 \\
42 \\
105 \\
\end{tabular} & $\begin{array}{l}2.76 \\
1.85 \\
2.44 \\
3.00 \\
1.83 \\
2.18\end{array}$ & \begin{tabular}{l|}
1.670 \\
1.040 \\
1.153 \\
1.897 \\
1.146 \\
1.343 \\
\end{tabular} & 2.889357 & $0.026 * *$ \\
\hline $\begin{array}{l}\text { Access to natural resources - } \\
\text { today }\end{array}$ & $\begin{array}{l}\text { Acquisition of state owned firm in privatization } \\
\text { Acquisition of domestic private firm } \\
\text { Acquisition of a domestic firm (private-public ownership) } \\
\text { Acquisition from another prior foreign investor } \\
\text { Ownership of completely new enterprise } \\
\text { Total }\end{array}$ & $\begin{array}{r}20 \\
20 \\
15 \\
7 \\
43 \\
105 \\
\end{array}$ & $\begin{array}{l}2.80 \\
2.00 \\
2.67 \\
2.86 \\
1.88 \\
2.26 \\
\end{array}$ & $\begin{array}{l}1.673 \\
1.214 \\
1.291 \\
1.864 \\
1.199 \\
1.401 \\
\end{array}$ & 2.455217 & 0.050565 \\
\hline $\begin{array}{l}\text { Access to local knowledge, } \\
\text { skills - entry }\end{array}$ & $\begin{array}{l}\text { Acquisition of state owned firm in privatization } \\
\text { Acquisition of domestic private firm } \\
\text { Acquisition of a domestic firm (private-public ownership) } \\
\text { Acquisition from another prior foreign investor } \\
\text { Ownership of completely new enterprise } \\
\text { Total }\end{array}$ & $\begin{array}{r}20 \\
17 \\
16 \\
7 \\
45 \\
105 \\
\end{array}$ & $\begin{array}{l}2.90 \\
2.88 \\
2.69 \\
3.57 \\
2.64 \\
2.80 \\
\end{array}$ & \begin{tabular}{r|}
.968 \\
1.166 \\
1.401 \\
1.272 \\
1.228 \\
1.204 \\
\end{tabular} & 0.995051 & 0.413947 \\
\hline $\begin{array}{l}\text { Access to local knowledge, } \\
\text { skills - today }\end{array}$ & $\begin{array}{l}\text { Acquisition of state owned firm in privatization } \\
\text { Acquisition of domestic private firm } \\
\text { Acquisition of a domestic firm (private-public ownership) } \\
\text { Acquisition from another prior foreign investor } \\
\text { Ownership of completely new enterprise } \\
\text { Total }\end{array}$ & $\begin{array}{r}21 \\
17 \\
16 \\
6 \\
46 \\
106\end{array}$ & $\begin{array}{l}3.05 \\
3.29 \\
3.19 \\
3.83 \\
2.91 \\
3.09\end{array}$ & $\begin{array}{l}1.024 \\
1.404 \\
1.515 \\
1.169 \\
1.262 \\
1.276\end{array}$ & 0.862781 & 0.489094 \\
\hline
\end{tabular}

$* * \mathrm{p}<0.05 ; * * * \mathrm{p}<0.01$

Second, ANOVA was performed to determine if the relative importance of entry motives differs in terms of ownership patterns of the equity (i.e. wholly owned subsidiaries (WOSs) or 
joint ventures (JVs). The results indicate that there is relatively weak support for Hypothesis 2. The relative importance of the entry motives hardly differs based on the type of ownership (WOS or JV) of foreign equity investors. Only a 'following foreign key clients' at entry factor shows a significant difference between WOSs and JVs, which indicates WOSs are more likely to have interest in market access to the host country than JVs. 
Table 4. The motivation of foreign equity shareholder in Croatia: ownership pattern

\begin{tabular}{|c|c|c|c|c|c|}
\hline Motivation & Group & Mean & Std. Deviation & $\mathrm{F}$ & Sig. \\
\hline \multirow{3}{*}{ Market access - entry } & Wholly-Owned Subsidiaries & 3.37 & 1.239 & \multirow{3}{*}{.275} & \multirow{3}{*}{.601} \\
\hline & Joint Ventures & 3.51 & 1.380 & & \\
\hline & Total & 3.46 & 1.333 & & \\
\hline \multirow{3}{*}{ Market access - today } & Wholly-Owned Subsidiaries & 3.26 & 1.349 & \multirow{3}{*}{2.015} & \multirow{3}{*}{.158} \\
\hline & Joint Ventures & 3.64 & 1.334 & & \\
\hline & Total & 3.52 & 1.344 & & \\
\hline \multirow{3}{*}{ Following key clients -entry } & Wholly-Owned Subsidiaries & 2.26 & 1.238 & \multirow{3}{*}{6.138} & \multirow{3}{*}{$.015^{* *}$} \\
\hline & Joint Ventures & 1.73 & .947 & & \\
\hline & Total & 1.90 & 1.072 & & \\
\hline \multirow{3}{*}{$\begin{array}{l}\text { Following key clients - } \\
\text { today }\end{array}$} & Wholly-Owned Subsidiaries & 2.39 & 1.345 & \multirow{3}{*}{2.814} & \multirow{3}{*}{.096} \\
\hline & Joint Ventures & 1.96 & 1.187 & & \\
\hline & Total & 2.09 & 1.248 & & \\
\hline \multirow{3}{*}{ Increased efficiency - entry } & Wholly-Owned Subsidiaries & 3.29 & 1.219 & \multirow{3}{*}{.005} & \multirow{3}{*}{.945} \\
\hline & Joint Ventures & 3.31 & 1.249 & & \\
\hline & Total & 3.31 & 1.234 & & \\
\hline \multirow{3}{*}{$\begin{array}{c}\text { Increased efficiency - } \\
\text { today }\end{array}$} & Wholly-Owned Subsidiaries & 3.61 & 1.321 & \multirow{3}{*}{.256} & \multirow{3}{*}{.614} \\
\hline & Joint Ventures & 3.47 & 1.224 & & \\
\hline & Total & 3.51 & 1.249 & & \\
\hline \multirow{3}{*}{$\begin{array}{l}\text { Access to natural } \\
\text { resources - entry }\end{array}$} & Wholly-Owned Subsidiaries & 2.26 & 1.189 & \multirow{3}{*}{.173} & \multirow{3}{*}{.678} \\
\hline & Joint Ventures & 2.15 & 1.411 & & \\
\hline & Total & 2.19 & 1.341 & & \\
\hline \multirow{3}{*}{$\begin{array}{l}\text { Access to natural } \\
\text { resources - today }\end{array}$} & Wholly-Owned Subsidiaries & 2.33 & 1.267 & \multirow{3}{*}{.127} & \multirow{3}{*}{.722} \\
\hline & Joint Ventures & 2.23 & 1.439 & & \\
\hline & Total & 2.26 & 1.383 & & \\
\hline \multirow{3}{*}{$\begin{array}{c}\text { Access to local knowledge, } \\
\text { skills - entry }\end{array}$} & Wholly-Owned Subsidiaries & 2.89 & 1.255 & \multirow{3}{*}{.126} & \multirow{3}{*}{.723} \\
\hline & Joint Ventures & 2.80 & 1.193 & & \\
\hline & Total & 2.83 & 1.208 & & \\
\hline \multirow{3}{*}{$\begin{array}{c}\text { Access to local knowledge, } \\
\text { skills - today }\end{array}$} & Wholly-Owned Subsidiaries & 3.24 & 1.275 & \multirow{3}{*}{.461} & \multirow{3}{*}{.499} \\
\hline & Joint Ventures & 3.07 & 1.237 & & \\
\hline & Total & 3.12 & 1.245 & & \\
\hline
\end{tabular}

$* * \mathrm{p}<0.05 ; * * * \mathrm{p}<0.01$

Third, ANOVA was conducted to test for the effect of subsidiary roles on technology transfer with F-test concerning Hypothesis 4 . Table 6 presents confidence intervals for past transfer of new products, past transfer of new markets and past transfer of new functions, first for each of the group (category) in subsidiaries abroad under firm's own control and then for all observations. This study found sufficient evidence to reject null hypothesis for both cases of past transfer of new products and new markets. The results suggested that there were statistical significant differences between two groups in both cases of transfer of new products $(\mathrm{F}=16.683$, $\mathrm{p}<0.0001)$ and new markets $(\mathrm{F}=4.224, \mathrm{p}<0.05)$ respectively. Consequently, the firm which has subsidiary abroad is likely to be more intensively involved in transfer of new products as 
well as transfer of new markets than the firm without subsidiary abroad. This paper, however, could not find significant difference between two groups in transfer of new business functions $(\mathrm{F}$ $=2.808, \mathrm{p}>0.05)$.

Table 5. Structure of supplies and sales across the sample

\begin{tabular}{|c|c|c|c|c|c|c|c|}
\hline & \multirow{2}{*}{$\frac{\mathrm{N}}{\text { Statistic }}$} & \multirow{2}{*}{$\begin{array}{c}\text { Mean } \\
\text { Statistic }\end{array}$} & \multirow{2}{*}{$\frac{\text { Std. Deviation }}{\text { Statistic }}$} & \multicolumn{2}{|c|}{ Skewness } & \multicolumn{2}{|c|}{ Kurtosis } \\
\hline & & & & Statistic & Std. Error & Statistic & Std. Error \\
\hline $\begin{array}{l}\text { Sales (\%) - to foreign } \\
\text { inves tor network }\end{array}$ & 141 & 30.03 & 36.807 & .907 & .204 & -.783 & .406 \\
\hline $\begin{array}{l}\text { Sales (\%) - to other } \\
\text { foreign buyers }\end{array}$ & 141 & 26.21 & 31.811 & 1.111 & .204 & -.023 & .406 \\
\hline $\begin{array}{l}\text { Sales }(\%) \text { - to domestic } \\
\text { subsidiaries of foregin } \\
\text { investor }\end{array}$ & 141 & 2.10 & 11.832 & 7.312 & .204 & 55.335 & .406 \\
\hline $\begin{array}{l}\text { Sales }(\%) \text { - to other } \\
\text { domestic firms }\end{array}$ & 141 & 40.14 & 37.892 & .367 & .204 & -1.511 & .406 \\
\hline $\begin{array}{l}\text { Supplies (\%) - from } \\
\text { foreign investor }\end{array}$ & 138 & 20.41 & 27.591 & 1.608 & .206 & 1.623 & .410 \\
\hline $\begin{array}{l}\text { Supplies (\%) - from other } \\
\text { imports }\end{array}$ & 138 & 32.42 & 30.240 & .726 & .206 & -.623 & .410 \\
\hline $\begin{array}{l}\text { Supplies (\%) - from } \\
\text { domestic subsidiaries of } \\
\text { foreign investor }\end{array}$ & 138 & 4.56 & 15.795 & 4.141 & .206 & 17.657 & .410 \\
\hline $\begin{array}{l}\text { Supplies (\%) - from other } \\
\text { domestic firms }\end{array}$ & 138 & 42.83 & 30.914 & .147 & .206 & -1.218 & .410 \\
\hline Valid N (lis twise) & 137 & & & & & & \\
\hline
\end{tabular}

Table 6. Descriptive stat of 'With Subsidiary abroad group' and 'Without group'.

Descriptives

\begin{tabular}{|c|c|c|c|c|c|c|c|c|c|}
\hline & & \multirow[b]{2}{*}{$\mathrm{N}$} & \multirow[b]{2}{*}{ Mean } & \multirow[b]{2}{*}{ Std. Deviation } & \multirow[b]{2}{*}{ Std. Error } & \multicolumn{2}{|c|}{$\begin{array}{l}95 \% \text { Confidence Interval for } \\
\text { Mean }\end{array}$} & \multirow[b]{2}{*}{ Minimum } & \multirow[b]{2}{*}{ Maximum } \\
\hline & & & & & & Lower Bound & Upper Bound & & \\
\hline \multirow{3}{*}{$\begin{array}{l}\text { Past transfer of resp. - } \\
\text { new markets }\end{array}$} & Subsidiaries abroad & 11 & 2.36 & .809 & .244 & 1.82 & 2.91 & 1 & 3 \\
\hline & None & 95 & 1.72 & 1.007 & .103 & 1.51 & 1.92 & 1 & 4 \\
\hline & Total & 106 & 1.78 & 1.005 & .098 & 1.59 & 1.98 & 1 & 4 \\
\hline \multirow{3}{*}{$\begin{array}{l}\text { Past transfer of resp. - } \\
\text { new products }\end{array}$} & Subsidiaries abroad & 14 & 2.93 & 1.072 & .286 & 2.31 & 3.55 & 1 & 4 \\
\hline & None & 92 & 1.73 & 1.017 & .106 & 1.52 & 1.94 & 1 & 4 \\
\hline & Total & 106 & 1.89 & 1.098 & .107 & 1.68 & 2.10 & 1 & 4 \\
\hline \multirow{3}{*}{$\begin{array}{l}\text { Past transfer of resp. - } \\
\text { new functions }\end{array}$} & Subsidiaries abroad & 10 & 2.10 & 1.101 & .348 & 1.31 & 2.89 & 1 & 4 \\
\hline & None & 90 & 1.56 & .961 & .101 & 1.35 & 1.76 & 1 & 4 \\
\hline & Total & 100 & 1.61 & .984 & .098 & 1.41 & 1.81 & 1 & 4 \\
\hline
\end{tabular}

Table 7. The results of ANOVA

\begin{tabular}{|ll|r|r|r|r|r|}
\hline \multicolumn{1}{|c|}{ ANOVA } & \multicolumn{1}{c|}{ Sum of } & \multicolumn{1}{c|}{ df } & Mean Square & F \\
\hline Past transfer of resp. - & Between Groups & 4.138 & 1 & 4.138 & 4.224 & .042 \\
& Within Groups & 101.872 & 104 & .980 & \\
& Total & 106.009 & 105 & & \\
\hline Past transfer of resp. - & Between Groups & 17.506 & 1 & 17.506 & 16.683 & .000 \\
new products & Within Groups & 109.135 & 104 & 1.049 & \\
& Total & 126.642 & 105 & & \\
\hline Past transfer of resp. - & Between Groups & 2.668 & 1 & 2.668 & 2.808 \\
new functions & Within Groups & 93.122 & 98 & .950 & .097 \\
& Total & 95.790 & 99 & & \\
\hline
\end{tabular}


Finally, CFA with full information maximum likelihood using SPSS Amos 22 was performed to establish the measurement of the constructs in the model. A major component of a CFA is to test the reliability of the observed variables (Schreiber, Nora, Stage, Barlow, \& King, 2006). Initial measure items was constructed, based on the knowledge of the theory, empirical research through the literature review. The chi-square value was insignificant, $\chi^{2}(51)=55.785, p$ $=0.3$, indicating good fit to the data (Hooper, Coughlan, \& Mullen, 2008). The chi-square statistic is sensitive to sample size and several other conditions. Alternative fit indices were also examined to decide whether the model fit was adequate. Alternative fit indices indicated highly acceptable fit, $\mathrm{CFI}=0.991, \mathrm{IFI}=.992, \mathrm{TLI}=.987, \mathrm{RMSEA}=0.026$. All measure items loaded significantly on their intended constructs, demonstrating convergent validity. All results of CFA are presented in table 8 and 9.

Table 8. CFA, Fit Indexes and Variance Accounted for in Three Latent Variable Models

\begin{tabular}{|lccccccc|}
\hline \multicolumn{1}{c}{ Factors } & $\chi 2$ & df & $\chi 2 / \mathrm{df}$ & TLI & IFI & CFI & RMSEA \\
\hline \hline One Factor & 272.287 & 54 & 5.042 & 0.433 & 0.624 & 0.608 & 0.168 \\
Two Factors & 108.966 & 53 & 2.056 & 0.852 & 0.904 & 0.899 & 0.086 \\
Three Factors & 55.785 & 51 & 1.094 & 0.987 & 0.992 & 0.991 & 0.026 \\
\hline
\end{tabular}


Table 9. The output of three factor loadings

\begin{tabular}{|lccc|}
\hline \multicolumn{1}{|c}{ Observed variables } & Latent construct & $\begin{array}{c}\text { Standardized } \\
\text { Loading }\end{array}$ & S.E. \\
\hline \hline & $\begin{array}{c}\text { Technology } \\
\text { Transfer }\end{array}$ & & \\
• Past transfer of new markets & & 0.73 & 0.096 \\
- Past transfer of new products & & 0.98 & 0.1 \\
- Past transfer of new functions & & 0.83 & 0.094 \\
\hline & Business & \\
& Performance & 0.67 & 0.102 \\
• Changes - Earnings before interest and tax & & 0.57 & 0.079 \\
• Changes - Share of exports in sales & & 0.77 & 0.078 \\
• Changes - Value added per employee & 0.82 & 0.077 \\
- Changes - Market share on the main market & & 0.82 & 0.073 \\
• Changes - Your competitive position in general & & 0.73 & 0.074 \\
• Changes - Competition within foreign investor & & & \\
network & Innovation & \\
\hline & Activities & 0.83 & 0.157 \\
• Production innovation & & 0.8 & 0.152 \\
• Process innovation & & 0.5 & 0.119 \\
\hline
\end{tabular}

Additionally, Cronbach's alpha was tested to probe reliability of data. Cronbach's alpha is widely employed as a measure for assessing construct reliability of a set of questions in a survey instrument. Cronbach's alpha is a coefficient that describes how well a group of items focuses on a single idea or construct (Cronbach, 1951). The alpha coefficient over 0.70 is considered an adequate level of internal consistency estimate (Nunnally, 1967), although cutoff value of alpha coefficient varies in specific contexts based on the number of items being loaded. Cronbach's alpha of all three latent variables (Technology transfer (0.878), Business performance (0.848), and Innovation activities (0.773)) was acceptable level of reliability. 


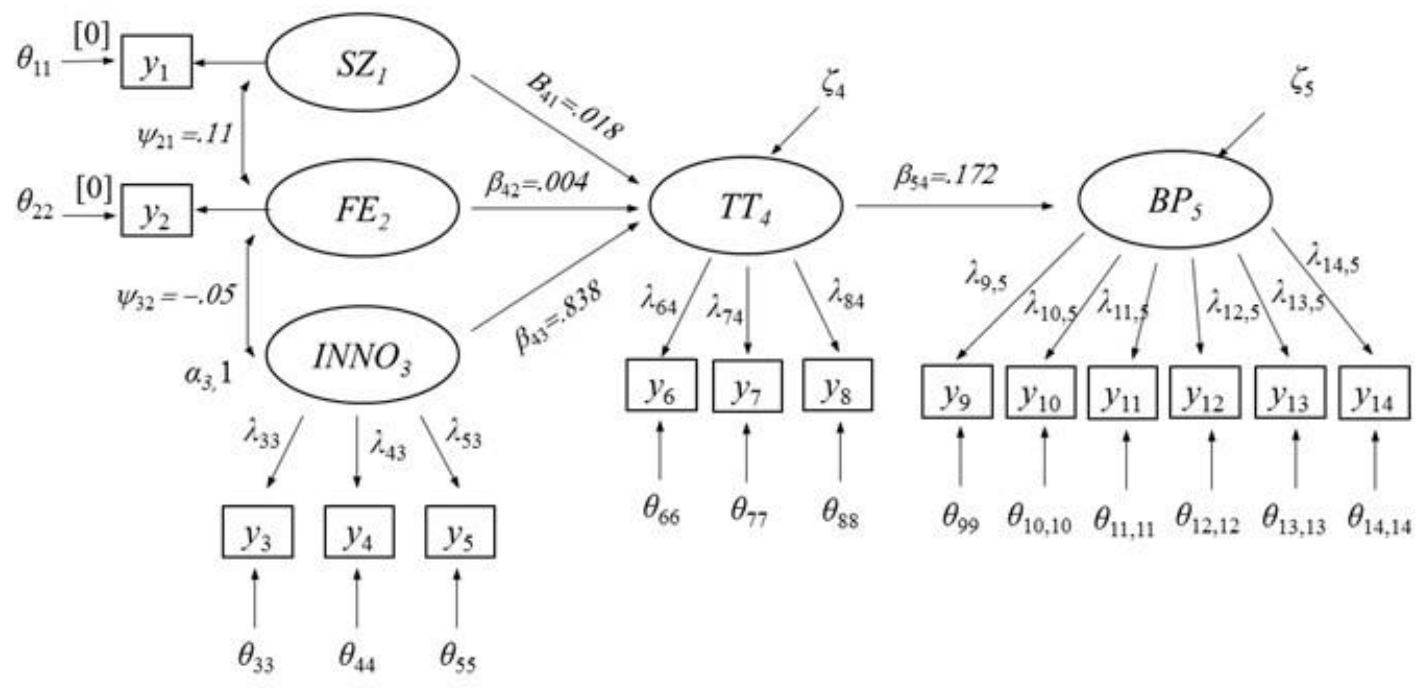

Fig. 2 Results for the hypothesized structural equation model

The graphic representation shown in Figure 2 is the hypothesized model that was tested to see how technology transfer affects the business performance. The SEM in Figure 2 illustrates the associations among latent constructs and observable variables as a succession of four structural equations. SEM technique, as implemented by SPSS AMOS 22 and R-package Lavaan 0.5-18, was used for data analyses. The following fit indices were considered: Comparative Fit Index (CFI), Bollen's Incremental Fit Index (IFI), Tucker-Lewis Index (TLI) and the Root Mean Square Error of Approximation (RMSEA). Most of these fit indices are computed by using ratios of the model chi-square and the null model chi-square taking into account their degrees of freedom. An earlier convention used above .90 as a cutoff for good fitting models, but $\mathrm{Hu} \&$ Bentler suggest that there seems to be some consensus now that this value should be increased to approximately .95 (Hooper et al., 2008).

Missing data as same as given dataset is a pervasive issue in the social sciences. When the data is not missing completely at random, dropping incomplete data results in sacrificing information from the sample and can lead to biased estimates. In recent years, probably the most pragmatic missing data estimation approach for structural equation modeling is full information maximum likelihood (FIML), which has been shown to produce unbiased parameter estimates 
and standard errors under missing at random(MAR) and missing completely at random(MCAR). Just "ML" is currently available in all major SEM packages. In this analysis, I used FIML to deal with missing value as well.

The model was then tested with SEM using SPSS Amos 22. The chi-square value was insignificant, $\chi^{2}(72)=76.181, p=0.346$, indicating good fit to the data. Alternative fit indices were also examined to determine whether the fit was adequate. Alternative fit indices suggested highly acceptable fit, $\mathrm{CFI}=0.992, \mathrm{IFI}=.993, \mathrm{TLI}=.989, \mathrm{RMSEA}=0.02$. All measure items loaded significantly on their intended constructs, demonstrating convergent validity. The results for the hypotheses are presented in Table 10.

Hypothesis 3 theorized that foreign ownership would have positive association with technology transfer between MNC and local partners. We found no significant evidence supporting H3 (standardized $\beta=.004, \mathrm{p}>.05$ ). However, the results support Hypothesis 5 and suggest that domestic innovation intensity have a positive relationship with the efficacy of technology transfer (standardized $\beta=2.557, \mathrm{p}<.05$ ). Hypothesis 6 argued that the firm size would have a positive association with technology transfer between MNC and local partners. The results do not support H6 (standardized $\beta=.018, \mathrm{p}>.05$ ). Finally, we found significant evidence supporting $\mathrm{H} 7$ (standardized $\beta=.172$ and $\mathrm{p}<.05$ ) and indicating that technology transfer between MNC and local partners has a positive relationship with the performance of subsidiaries.

Table 10. Test results of the path model

\begin{tabular}{|lcccccc|}
\hline \multicolumn{1}{|c}{ Description } & Path & Hypothesis & Estimate & \multicolumn{1}{c|}{ S.E. } & p \\
\hline \hline Size (SZ) --> Technology Transfer (TT) & SZ --> TT & H6 & 0.018 & 0.012 & 0.132 \\
Foreign Ownership (FE) --> TT & FE --> TT & H3 & 0.004 & 0.003 & 0.246 \\
Innovation Activities (INNO) --> TT & INNO --> TT & H5 & 0.838 & 0.267 & $0.002 * *$ \\
TT --> Business Performance (BP) & TT --> BP & H7 & 0.172 & 0.068 & $0.012 *$ \\
\hline
\end{tabular}

Note: $*: \mathrm{p}<0.05, * *: \mathrm{p}<0.0$

\section{Discussion}

The analyses showed that there was enough evidence to support Hypotheses 4, 5 and 7; weak evidence to support Hypotheses 1 and 2 and no evidence to support Hypothesis 3 or 6 . Table 11 summarizes the results. 
Table 11 Hypothesis Testing Summary

\begin{tabular}{|l|l|l|}
\hline $\begin{array}{l}\text { Hypothesis } \\
\text { Number }\end{array}$ & Hypothesis & Result \\
\hline 1 & $\begin{array}{l}\text { The relative importance of motives will vary } \\
\text { with the market entry mode }\end{array}$ & Weak Support \\
\hline 2 & $\begin{array}{l}\text { The relative importance of motives will differ } \\
\text { based on the ownership pattern of the equity }\end{array}$ & Weak Support \\
\hline 3 & $\begin{array}{l}\text { The higher foreign ownership leads to more } \\
\text { efficient technology transfer }\end{array}$ & Not Supported \\
\hline 4 & $\begin{array}{l}\text { Abroad subsidiaries are positively correlated } \\
\text { with technology transfer of foreign investment } \\
\text { companies }\end{array}$ & Supported \\
\hline 5 & $\begin{array}{l}\text { The higher domestic innovation intensity boost } \\
\text { efficacy of technology transfer }\end{array}$ & Supported \\
\hline 6 & $\begin{array}{l}\text { The subsidiary's size will affect technology } \\
\text { transfer activities within organization }\end{array}$ & Not Supported \\
\hline 7 & $\begin{array}{l}\text { Technology transfer from the MNC to } \\
\text { subsidiaries has a positive association with the } \\
\text { business performance of subsidiaries. }\end{array}$ & Supported \\
\hline
\end{tabular}

The results suggest that motives of the firms may determine the market entry mode and the type of ownership. Since there was only limited support for the Hypotheses 1 and 2, it is hard to speculate if this would be generalizable to other countries of Croatia's size in Europe. On the other hand, presence of subsidiaries abroad and high domestic innovation intensity were found to yield more technology transfer which overall results in improved business performance (Hypotheses 4,5 and 7). This result is generalizable to countries of Croatian size in Europe. The recommendation out of this is that the governments of countries similar to Croatia - smaller developing countries in Europe - should support policies which would encourage multinational 
companies entering into their domestic markets and domestic innovations to flourish. The size of the subsidiary or the higher foreign ownership do not impact the results, so the governments should consider this while setting up their policies.

These results could be a basis for further research in investigating the science and innovation policies related to FDI. Future research can investigate how the policies in the last decade have impacted innovation using the constructs presented in this paper. The high level hypothesis would be that the policies have helped innovation intensity and technology transfer to increase and both yielding better business performance.

\section{Conclusion}

This study analyzes the effects of FDI on innovation activities between MNC and local partners. This paper attempts to examine whether subsidiaries acquire technology internationally, typically from their parent MNC. The results indicate that innovation activities in MNC subsidiaries have a positive influence toward technology transfer from MNCs, while firm size and intensity of foreign ownership does not. This result is harmonious with the claim of Veugler and Cassiman (Veugelers \& Cassiman, 2004) suggesting that foreign affiliates with innovation active have a tendency to acquire technology internationally. We can conclude that innovation activity factors have a direct impact on technology transfer. This result provides an insight how to stimulate technology transfer from international firms. The data indicate that technology spillovers are associated with projects they involve.

Finally, this study examines the association between technology transfer from MNC and the business performance of MNC subsidiaries. The result, based on firm-level data from Croatia, provides evidence with positive technology spillovers FDI between MNCs and their subsidiaries. This finding is consistent with the widely-cited Javorcik's work (Javorcik, 2004) claiming that the productivity of domestic firms has a positive association with the presence of MNCs in downstream sectors. Consequently, we can argue that MNCs improve the performance of affiliates through knowledge spillovers.

\section{References}

Acs, Z. J., Audretsch, D. B., \& Feldman, M. P. (1994). R \& D spillovers and recipient firm size. 
Review of Economics and Statistics, 76(2), 336-340.

Aitken, B. J., \& Harrison, A. E. (1999). Do domestic firms benefit from direct foreign investment? Evidence from Venezuela. American Economic Review, 89(3), 605-618.

Andersson, U., Forsgren, M., \& Holm, U. (2002). The strategic impact of external networks: Subsidiary performance and competence development in the multinational corporation. Strategic Management Journal, 23(11), 979-996.

Bénassy-Quéré, A., Coupet, M., \& Mayer, T. (2007). Institutional determinants of foreign direct investment. The World Economy, 30(5), 764-782.

Blalock, G., \& Gertler, P. J. (2008). Welfare gains from Foreign Direct Investment through technology transfer to local suppliers. Journal of International Economics, 74(2), 402-421.

Blomström, M., \& Kokko, A. (1998). Multinational corporations and spillovers. Journal of Economic Surveys, 12(2), 247-277.

Blomström, M., Kokko, A., \& Zejan, M. (2000). Foreign Direct Investment: Firm and Host Country Strategies. London, Great Britain: Macmillan Press LTD.

Blomström, M., \& Sjöholm, F. (1999). Technology transfer and spillovers: Does local participation with multinationals matter? European Economic Review, 43(4-6), 915-923.

Boeh, K. K., \& Beamish, P. W. (2012). Travel time and the liability of distance in foreign direct investment: Location choice and entry mode. Journal of International Business Studies, 43(5), 525-535.

Bollen, K. A. (2002). Latent variables in psychology and the social sciences. Annual Review of Psychology, 53(1), 605-634.

Brouthers, K. D., Brouthers, L. E., \& Werner, S. (2008). Resource-based advantages in an international context. Journal of Management, 34(2), 189-217.

Buckley, P. J., Clegg, J., \& Wang, C. (2002). The impact of inward FDI on the performance of Chinese manufacturing firms. Journal of International Business Studies, 33(4), 637-655.

Cantwell, J., \& Mudambi, R. (2005). MNE competence- creating subsidiary mandates. Strategic Management Journal, 26(12), 1109-1128.

Chung, W. (2001). Identifying technology transfer in foreign direct investment: influence of industry conditions and investing firm motives. Journal of International Business Studies, 32(2), 211-229.

Cohen, W. M., \& Levinthal, D. a. (1990). Absorptive capacity: a new perspective on learning and innovation. Administrative Science Quarterly, 35(1), 128-152.

Cohen, W. M., \& Levinthal, D. A. (1989). Innovation and learning: the two faces of R\&D. The Economic Journal, 99(397), 569-596.

Cronbach, L. J. (1951). Coefficient alpha and the internal structure of tests. Psychometrika, 16(3), 297-334.

Cui, A. S., Griffith, D. A., Cavusgil, S. T., \& Dabic, M. (2006). The influence of market and cultural environmental factors on technology transfer between foreign MNCs and local subsidiaries: a Croatian illustration. Journal of World Business, 41(2), 100-111. 
Cusumano, M. A., \& Elenkov, D. (1994). Linking international technology transfer with strategy and management: a literature commentary. Research Policy, 23(2), 195-215.

Dabić, M., Daim, T. U., Aralica, Z., \& Bayraktaroglu, A. E. (2012). Exploring relationships among internationalization, choice for research and development approach and technology source and resulting innovation intensity: case of a transition country Croatia. Journal of High Technology Management Research, 23(1), 15-25.

de la Potterie, B. van P., \& Lichtenberg, F. (2001). Does foreign direct investment transfer technology across borders? Review of Economics and Statistics, 83(3), 490-497.

Dikova, D., \& van Witteloostuijn, A. (2007). Foreign direct investment mode choice: entry and establishment modes in transition economies. Journal of International Business Studies, 38(6), 1013-1033.

Dunning, J. H. (1988). The eclectic paradigm of international production: a restatement and some possible extensions. Journal of International Business Studies, 19(1), 1-31.

Erin Anderson, \& Gatignon, H. (1986). Modes of foreign entry: A transaction cost analysis and propositions. Journal of International Business Studies, 17(3), 1-26.

Ethier, W. J. (1986). The multinational firm. The Quarterly Journal of Economics, 101(4), 805834.

Ford, J. K., MacCallum, R. C., \& Tait, M. (1986). The application of exploratory factor analysis in applied psychology: a critical review and analysis. Personnel Psychology, 39(2), 291314.

Frost, T. S., Birkinshaw, J. M., \& Ensign, P. C. (2002). Centers of excellence in multinational corporations. Strategic Management Journal, 23(11), 997-1018.

Gomes-Casseres, B. (1989). Ownership structures of foreign subsidiaries: theory and evidence. Journal of Economic Behavior and Organization, 11(1), 1-25.

Görg, H., \& Greenaway, D. (2004). Much ado about nothing? Do domestic firms really benefit from foreign direct investment? World Bank Research Observer, 19(2), 171-197.

Griffith, R., Harrison, R., \& Reenen, J. Van. (2006). How special is the special relationship? Using the impact of US R\&D spillovers on UK firms as a test of technology sourcing. American Economic Review, 96(5), 1859-1875.

Guellec, D., \& de la Potterie, B. van P. (2001). The internationalisation of technology analysed with patent data. Research Policy, 30(8), 1253-1266.

Gupta, A. K., \& Govindarajan, V. (1991). Knowledge flows and the structure of control within multinational corporations. Academy of Management Review, 16(4), 768-792.

Gupta, A. K., \& Govindarajan, V. (1994). Organizing for knowledge flows within MNCs. International Business Review, 3(4), 443-457.

Gupta, A. K., \& Govindarajan, V. (2000). Knowledge flows within multinational corporations. Strategic Management Journal, 21(4), 473-496.

Harzing, A. W., \& Noorderhaven, N. (2006). Knowledge flows in MNCs: an empirical test and extension of Gupta and Govindarajan's typology of subsidiary roles. International Business Review. 
Hennart, J. (1988). A transaction costs theory of equity joint ventures. Strategic Management Journal, 9(4), 361-374.

Hennart, J.-F. (1991). The transaction costs theory of joint ventures: An empirical study of Japanese subsidiaries in the United States. Management Science, 37(4), 483-497.

Hennart, J.-F., \& Park, Y.-R. (1993). Greenfield vs. acquisition: the strategy of Japanese investors in the United States. Management Science, 39(9), 1054-1070.

Hennart, J.-F., \& Slangen, A. H. L. (2015). Yes, we really do need more entry mode studies! A commentary on Shaver. Journal of International Business Studies, 46(1), 114-122.

Hill, C. W. L., Hwang, P., \& Kim., W. C. (1990). An eclectic theory of the choice of international entry mode. Strategic Management Journal, 11(2), 117-128.

Hooper, D., Coughlan, J., \& Mullen, M. (2008). Structural equation modeling: Guidelines for determining model fit. Electronic Journal of Business Research Methods, 6(1), 53-60.

Hu, A. G. Z., Jefferson, G. H., \& Jinchang, Q. (2005). R\&D and technology transfer: firm-level evidence from Chinese industry. Review of Economics and Statistics, 87(4), 780-786.

Javorcik, B. S. (2004). Does foreign direct investment increase the productivity of domestic firms? In search of spillovers through backward linkages. American Economic Review, 94(3), 605-627.

Jindra, B., Giroud, A., \& Scott-Kennel, J. (2009). Subsidiary roles, vertical linkages and economic development: Lessons from transition economies. Journal of World Business, 44(2), 167-179.

Johanson, J., \& Vahlne, J.-E. (1977). The internationalization process of the firm-a model of knowledge development and increasing foreign market commitments. Journal of International Business Studies, 8(1), 23-32.

Kogut, B., \& Zander, U. (1993). Knowledge of the firm and the evolutionary theory of the multinational corporation. Journal of International Business Studies, 24(4), 625-645.

Lane, P. J., \& Lubatkin, M. (1998). Relative absorptive capacity and interorganizational learning. Strategic Management Journal, 19(5), 461-477.

Luo, Y., \& Park, S. H. (2001). Strategic alignment and performance of market-seeking MNCs in China. Strategic Management Journal, 22(2), 141-155.

Makino, S., \& Beamish, P. W. (1998). Performance and survival of joint ventures with nonconventional ownership structures. Journal of International Business Studies, 29(4), $797-$ 818.

Marin, A., \& Bell, M. (2006). Technology spillovers from Foreign Direct Investment (FDI): the active role of MNC subsidiaries in Argentina in the 1990s. Journal of Development Studies, 42(4), 678-697.

Markusen, J. R., \& Venables, A. J. (1999). Foreign direct investment as a catalyst for industrial development. European Economic Review, 43(2), 335-356.

Maruyama, G. M. (1998). Basics of Structural Equation Modeling. London: SAGE Publications.

Matsueda, R. L. (2012). Key Advances in the History of Structural Equation Modeling. In R. 
Hoyle (Ed.), Handbook of structural equation modeling (pp. 17-42). New York, NY: Guilford Press.

Morschett, D., Schramm-Klein, H., \& Swoboda, B. (2010). Decades of research on market entry modes: What do we really know about external antecedents of entry mode choice? Journal of International Management, 16(1), 60-77.

Mudambi, R., \& Navarra, P. (2004). Is knowledge power? Knowledge flows, subsidiary power and rent-seeking within MNCs. Journal of International Business Studies, 35(5), 385-406.

Neto, P., Brandão, A., \& Cerqueira, A. (2010). The impact of FDI, cross-border mergers and acquisitions, and greenfield investments on economic growth. Journal of Business Strategy, 7(4), 24-45.

Newsom, J. T. (2015). Longitudinal Structural Equation Modeling: A Comprehensive Introduction. Routledge.

Nunnally, J. C. (1967). Psychometric Theory. New York: McGraw-hill.

Pack, H., \& Saggi, K. (2001). Vertical technology transfer via international outsourcing. Journal of Development Economics, 65(2), 389-415.

Padmanabhan, P., \& Cho, K. R. (1996). Ownership strategy for a foreign affiliate: An empirical investigation of Japanese firms. Management International Review, 36(1), 45-65.

Patterson, W. C. (1983). Evaluating R\&D performance at Alcoa laboratories. Research Management, 26(2), 23-27.

Pavitt, K., Robson, M., \& Townsend, J. (1989). Technological accumulation, diversification and organisation in UK companies, 1945-1983. Management Science, 35(1), 81-99.

Pedersen, T., Petersen, B., \& Benito, G. R. G. (2002). Change of foreign operation method: Impetus and switching costs. International Business Review, 11(3), 325-345.

Pedhazur, E. J. (1997). Structural Equation Models with Observed Variables: Path Analysis. In Multiple Regression in Behavioral Research: Explanation and Prediction (3rd ed., pp. 765807). Fort Worth, TX: Harcourt Brace.

Pennings, J. M., \& Harianto, F. (1992). The diffusion of technological innovation in the commercial banking industry. Strategic Management Journal, 13(1), 29-46.

Perez, T. (1997). Multinational enterprises and technological spillovers: An evolutionary model. Journal of Evolutionary Economics, 7(2), 169-192.

Ramachandran, V. (1993). Technology transfer, firm ownership, and investment in human capital. The Review of Economics and Statistics, 75(4), 664-670.

Schreiber, J. B., Nora, A., Stage, F. K., Barlow, E. A., \& King, J. (2006). Reporting structural equation modeling and confirmatory factor analysis results: a review. The Journal of Educational Research, 99(6), 323-338. https://doi.org/10.3200/JOER.99.6.323-338

Sinani, E., \& Meyer, K. E. (2004). Spillovers of technology transfer from FDI: The case of Estonia. Journal of Comparative Economics, 32(3), 445-466.

Spencer, J. W. (2008). The impact of multinational enterprise strategy on indigenous enterprises: horizontal spillovers and crowding out in developing countries. Academy of Management 
Review, 33(2), 341-361.

Stopford, J. M., \& Wells, L. T. (1972). Managing the Multinational Enterprise: organization of the firm and ownership of the subsidiaries. New York: Basic Books.

Teece, D. J. (1977). Technology transfer by multinational firms: the resource cost of transferring technological know-how. The Economic Journal, 87(346), 242-261.

Veugelers, R., \& Cassiman, B. (2004). Foreign subsidiaries as a channel of international technology diffusion: some direct firm level evidence from Belgium. European Economic Review, 48(2), 455-476.

Wright, S. (1918). On the nature of size factors. Genetics, 3(4), 367.

Wright, S. (1934). The method of path coefficients. The Annals of Mathematical Statistics, 5(3), $161-215$.

Yiu, D., \& Makino, S. (2002). The choice between joint venture and wholly owned subsidiary: An institutional perspective. Organization Science, 13(6), 667-683.

Young, S., \& Lan, P. (1997). Technology transfer to China through foreign direct investment. Regional Studies, 31(7), 669-679.

Zahra, S. A., \& George, G. (2002). Absorptive capacity: a review, reconceptualization, and extension. Academy of Management Review, 27(2), 185-203. 